\title{
ANALISIS PENGUKURAN KINERJA MENGGUNAKAN METODE VALUE FOR MONEY PADA SATUAN KERJA BALAI PENELITIAN TAMANAN HIAS KAB. CIANJUR
}

\author{
PERFORMANCE MEASUREMENT ANALYSIS USING METHODS \\ VALUE FOR MONEY AT THE WORK UNIT OF THE ORNAMENT GARDEN RESEARCH \\ CENTER REGENCY CIANJUR
}

\author{
A.B.Setiawan, S.Anwar, A.Zamaludin, D.S. Anurul \\ Program studi Akuntansi Fakultas Ekonomi Universitas Djuanda Bogor \\ Jln. Tol Ciawi No.1, Kotak Pos 35, Kode Pos 16720, Telp/Fax: (0251) 8245155 \\ ade.budi.setiawan@unida.ac.id,saeful.anwar@unida.ac.id, ayi.jamaludin@unida.ac.id, \\ ndeuisa@gmail.com
}

\begin{abstract}
Performance measurement is the process of accumulating, analyzing and reporting information about the performance of a person, agency/company, system or division. The research design with the data used is the Performance Report for the period 2017-2018 with data analysis tools using the VFM method. The results of the study as a whole show that the performance of the Balithi Cianjur Regency for the 2017-2018 period of performance measurement is categorized as very good. Based on the VFM method in terms of the economic level in 2017-2018, it can be said to be very economical because the budget realization is smaller than the existing target. The level of efficiency in 2017 is categorized as efficient while in 2018 it is categorized as very efficient. The level of effectiveness in 20172018 is categorized as very effective.
\end{abstract}

Keywords: Performance, VFM, Economical, Efficiency, Effectiveness

\begin{abstract}
ABSTRAK
Pengukuran kinerja merupakan proses akumulasi, analisa dan pelaporan informasi mengenai kinerja seseorang, intansi/perusahaan, system atau bagian. Desain penelitian dengan data yang digunakan merupakan Laporan Kinerja pada periode tahun 2017-2018 dengan alat analisis data menggunakan metode VFM. Hasil penelitian secara keseluruhan menunjukan bahwa kinerja Balithi Kabupaten Cianjur periode 2017-2018 pengukuran kinerja dikategorikan sangat baik. Berdasarkan metode VFM ditinjau dari tingkat ekonomi pada tahun 2017-2018 dapat dikatakan sangat ekonomis karena realisasi anggaran lebih kecil dari pada target yang ada. Untuk tingkat efisiensi pada tahun 2017 dikategorikan efisien sedangkan tahun 2018 dikategorikan sangat efisien. Untuk tingkat efektivitas pada tahun 2017-2018 dikategorikan sangat efektif.
\end{abstract}

Kata Kunci: Kinerja, VFM, Ekonomis, Efisien, Efektifitas 


\section{PENDAHULUAN}

Peningkatan kinerja memiliki serangkaian prosesnya dimulai dari merencanakan hingga mengevaluasi kinerja. Balithi Cianjur melakukan peng- optimalisasian anggaran yang dilakukan secara ekonomis, efisiensi dan efektifitas.

Mahsun (2009), mengatakan kinerja itu stategi perencanaan organisasi yang didalamnya terdapat tujuan, sasaran, dan lainnya yang berupa gambaran mengenai level pencapaian kegiatan kebijakan.

Keberhasilan lembaga pemerintah akan bergantung pada kemampuan lembaga ini, dan lembaga ini akan mencapai hasil berdasarkan sumber daya yang diperoleh berdasarkan rencana yang diuraikan dalam rencana strategis pembangunan ekonomi.

Penggunaan indikator sumber daya untuk pengadaan pengukuran kinerja secara komprehensif, agar masyarakat dapat benar -benar mendapatkan hasil yang bermanfaat baik langsung maupun tidak langsung untuk setiap perhitungan kebijakan yang mana akuntanbilitas kinerja dapat dapat diwujudkan program pelaksanaanya. (Setiawan dan Gusti, 2017) (Mahmudi, 2007)

Bentuk pertanggungjawaban kinerja diharuskan untuk dilaporkan sebagai bentuk hasil pengukuran kinerja sektor public. Barnett, C., et.al. (2010) VFM adalah tentang mendapatkan manfaat maksimum dari waktu ke waktu dengan sumber daya yang tersedia. Ini tentang mencapai lokal yang tepat keseimbangan antara ekonomi, efisiensi dan efektivitas, atau pengeluaran lebih sedikit, pengeluaran dengan baik dan pengeluaran dengan bijak untuk mencapai prioritas lokal.

Menurut Mahmudi (2010), VFM merupakan apresiasi nilai mata uang, oleh karena itu setiap rupee harus diapresiasi dan digunakan semaksimal mungkin. VFM adalah evaluasi kinerja, yang merupakan inti dari organisasi pemerintah dan sektor publik. Kinerja pemerintah tidak dapat dievaluasi hanya berdasarkan output yang dihasilkan, akan tetapi input, output dan hasil harus dipertimbangkan secara komprehensif sehingga benar-benar mencerminkan kinerja pemerintah.

Mardiasmo (2004) VFM adalah konsep pengelolaan organisasi sektor publik yang didasarkan pada tiga unsur utama yaitu ekonomi, efisiensi dan efektivitas. Elemen pertama dari konsep VFM adalah ekonomi. Ekonomi adalah pendapatan. Masukkan masukan dengan kualitas dan kuantitas tertentu dengan harga rendah/terendah. Untuk menghindari pemborosan dan mengurangi pengeluaran produksi, ini sebuah langkah bagi organisasi sektor publik untuk meminimalkan sumber daya input mereka. Elemen kedua adalah efisiensi. Efisiensi adalah realisasi tingkat keluaran atau keluaran tertentu dengan menggunakan masukan terendah / minimum Memiliki masukan khusus. Unsur terakhir adalah efektivitas. Efektivitas mengacu pada tingkat pencapaian hasil yang direncanakan sesuai dengan tujuan yang telah ditentukan sebelumnya. Sederhananya, efektivitas adalah perbandingan hasil dan keluaran.

Penelitian sebelumnya Wiwik (2013), tentang penggunaan analisis VFM untuk mengukur kinerja keuangan sektor publik (mengambil contoh Pemerintah Bojonegoro). Peneliti sampai pada suatu kesimpulan. Tingkat ekonomi yang dihitung dari tahun 2008 hingga 2011, efisiensi dan manfaat masing-masing sebesar $89,70 \%, 90,17 \%$ dan $87,45 \%$ dari tingkat ekonomi.Hasil perhitungan tersebut menunjukkan bahwa kinerja keuangan pemerintah Pocionegro dalam hal penghematan biaya telah tercapai. Penurunan tahun ke tahun dalam proyekproyek tidak ekonomis menunjukkan hal ini. Hasil perhitungan efisiensi masingmasing sebesar $3,82 \%, 1,99 \%$ dan $1,50 \%$. Kinerja pemerintah efisien. Bahkan jika pengeluaran meningkat, pemerintah dapat mengimbanginya. Meningkatkan pendapatan, terutama pendapatan dari PAD.

Hasil perhitungan menunjukkan bahwa tingkat efektivitas $101.08 \%$, 98\%, 
$104.34 \%$ dan $109.66 \%$ dicapai karena optimalisasi pemungutan oleh pemerintah dalam proses akuisisi. Pendapatan dari PAD.

Judul penelitian Yuanda (2007) adalah evaluasi kinerja organisasi sektor publik dengan menggunakan metode PKS (mengambil contoh Pemerintah Kota Blitar). Tujuan penelitiannya untuk mengevaluasi kinerja Pemkot Blitar, jika metode VFM digunakan untuk mengevaluasi apakah kinerja Pemkot Blitar ekonomis dan efisien. Dan itu berhasil. Teknologi analisis data yang digunakan untuk mengukur kinerja keuangan Pemerintah Kota Blitar menggunakan metode VFM untuk menghitung rasio ekonomi, rasio efisiensi dan rasio efektivitas.

Selain ketiga rasio tersebut, terdapat pula rasio kemandirian daerah, rasio aktivitas, rasio pertumbuhan dan DSCR, dimana rasio tersebut adalah. Ini adalah suplemen untuk metode VFM. Rasio ekonomi yang dihitung untuk tahun ajaran 2003-2005 adalah 96,76\%, 95,16\% dan 94,62\%. Rasio efisiensi untuk tahun anggaran 2002-2005 adalah 99\%, 1,01\% dan $98 \%$. Sementara itu, tingkat efektif untuk tahun anggaran 2003-2005 adalah $115,4 \%, 149,8 \%$ dan $126,9 \%$.

Mardiasmo (2009) menyatakan manfaat pengukuran kinerja dalam organisasi sektor publik sebagai berikut:

a. Pemahaman tentang ukuran yang untuk penilaian kinerja manajemen.

b. Memberikan arahan untuk sesuai rencana yang dituangkan.

c. Pantau, awasi pencapaian kinerja, dan bandingkan dengan tujuan kinerja, dan ambil tindakan kolektif untuk meningkatkan kinerja.

d. Penghargaan dan hukuman.

e. Alat komunikasi bottom-up dengan atasan untuk meningkatkan kinerja organisasi.

f. Membantu menentukan apakah akan memenuhi kepuasan pelanggan.

g. Membantu memahami rencana/ kebijakan lembaga pemerintah. h. Pastikan pengambilan keputusan yang mendalam dan obyektif.

Mardiasmo (2005), tujuan sistem pengukuran kinerja antara lain:

a. Strategi komunikasi atau Mengkomunikasikan strategi (top down and bottom up).

b. Seimbangkan pengukuran kinerja keuangan dan non-keuangan. Untuk mencapai konsensus dalam pengembangan strategis.

c. Memahami kepentingan manajer menengah dan bawah dan motivasi untuk mencapai konsistensi yang baik.

d. Alat kepuasan berbasis metode. Kemampuan individu dan kolektif yang rasional.

Instansi pemerintah bertujuan untuk memberikan pelayanan publik berupa kepuasan kepada masyarakat. Pencapaian kepuasan masyarakat ini menuntut kinerja instansi pemerintah berupa kualitas pelayanan Sinambela (2006) yang tercermin dari:

a. Transparansi, suatu pelayanan yang bersifat terbuka, ringan dan dapat diakses semua pihak dan disediakan secara memadai serta cepat dimengerti;

b. Sistem akuntabilitas, yaitu dapat melakukan jasa perlakuan akuntansi yang sesuai dengan hukum;

c. Secara bersyarat, layanan harus memenuhi kondisi dan kemampuan penyedia dan penerima. Mematuhi prinsip efisiensi dan efektivitas;

d. Pelayanan partisipatif untuk mendorong I menginspirasi masyarakat agar berpartisipasi dalam penyelenggaraan pelayanan publik, dengan tetap memperhatikan keinginan, kebutuhan dan harapan masyarakat;

e. Persamaan hak dan layanan nondiskriminatif tercermin dalam beberapa aspek, terutama ras, ras, agama, dll .;

f. Keseimbangan antara hak dan kewajiban serta pelayanan memperhatikan aspek keadilan antara penyedia dan penerima layanan publik.

(Setiawan, A.B. dan W, Gusnita, 2016) Sektor publik seringkali dilihat 
sebagai sarang pemborosan, karena menyerap anggaran yang tidak tepat, Apalagi anggaran melebihi batas atas anggaran DIPA, sehingga ada persyaratan baru yang menuntut organisasi lebih memperhatikan kinerjanya, dan hasil pengukuran kinerja harus dilaporkan dalam bentuk akuntabilitas kinerja.

Beberapa metode pengukuran kinerja antara lain: BSD dan VFM, dan metode penelitiannya adalah VFM. Metode penilaian kinerja BSC didasarkan pada perspektif keuangan dan non keuangan, sedangkan VFM bersifat multidimensi, yang berarti bahwa satu indikator tidak dapat digunakan untuk menunjukkan kinerja instansi pemerintah. Secara komprehensif.

Selain itu, dalam studi tahun 2015 yang dilakukan oleh Ardila dan Putri di Pengadilan Negeri Tebing Tinggi (Sumatera Utara), realisasi anggaran melebihi $100 \%$ yang menunjukkan bahwa kinerja lembaga tersebut tidak sesuai dengan ketentuan. Seperti kita ketahui bersama, buruknya kinerja lembaga/ perusahaan hanya dapat dilihat dari laporan keuangannya saja, tetapi bisa dari LAKIP.

VFM adalah inti dari pengukuran kinerja sektor publik, karena kinerja pemerintah tidak dapat dinilai hanya berdasarkan output yang dihasilkan, tetapi input, output dan hasil harus dipertimbangkan secara komprehensif.

Ekonomi merupakan pengeluaran yang seminimal mungkin untuk mendapatkan output berkualitas dan kuantitas tertentu. Efisiensi yaitu berkaitan dengan hubungan antara input dan output agar mencapai tujuan tertentu, artinya melakukan kegiatan yang tepat guna, sedangkan efektivitas adalah pencapaian suatu organisasi/intansi dengan visi dan misi serta rencana kerja dalam periode terkait. VFM dapat dicapai bila suatu organisasi dapat menggunakan input terendah untuk mencapai output yang maksimal sebagai bentuk pencapaian tujuan organisasi. Selain VFM, realisasi tujuan organisasi juga merupakan sistem akuntabilitas. Akuntabilitas merupakan hasil evaluasi kinerja dalam bentuk LAKIN. Harus lapor. Laporan kinerja merupakan bentuk transparan dan tanggung jawab bagi IAEA (Balich) untuk menjalankan tugas dan fungsinya kepada publik guna mencapai tujuan kegiatan yang tertuang dalam Perjanjian Kinerja (PK).

Laporan kinerja disusun dengan mengacu pada Peraturan Presiden Nomor 29 Tahun 2015 Republik Indonesia yang mengatur tentang Peraturan Akuntabilitas Kinerja Instansi Pemerintah (SAKIP) Kementerian Pendayagunaan Aparatur Negara dan Reformasi Birokrasi, dan Nomor 53 Tahun 2015 terkait dengan pedoman teknis perjanjian kinerja. Laporan kinerja dan prosedur untuk mereview laporan kinerja instansi pemerintah. LAKIN meliputi rencana dan kesepakatan kinerja, pelaksanaan kegiatan, pertanggungjawaban dan evaluasi kinerja.

Lasmana dan Nofiyati (2017) Keberhasilan capaian kinerja dalam satu periode didukung oleh konsistensi dan tanggung jawab pada pelaksanaan tugas pokok. dan fungsi sebagai instansi pemerintah. Selain itu, ketika terjadinya kendala yang ada harus sesegera mungkin ditindak lanjuti untuk memperbaiki kinerja dimasa depan/tahun berikutnya.

Pengukuran kinerja dengan menggunakan metode VFM didukung dengan adanya grand teori (Donaldson, 1991) Teori Agensi dan stewardship theory, pemerintah sebagai (Principal) yang punya kewenangan, kemudian kepala balai sebagai (agent) sebagai pengguna anggaran.

Adapun salah satu instansi pemerintah di Cianjur yang menarik perhatian penelitian ini ialah Balithi Kab. Cianjur yang berhubungan dengan penelitian dan pengembangan tanaman hias, Balithi merupakan satu dari sekian entitas akuntansi di bawah kementerian pertanian yang berkewajiban menyelenggarakan akuntansi dan laporan 
pertanggungjawaban atas pelaksanaan APBN dengan menyusun dan menyampaikan laporan keuangan berupa Laporan Realisasi Anggara, Laporan posisis Keuangan, dan Catatan atas Laporan Keuangan. Selain itu, Lembaga pemerintah diharuskan/ wajibkan melaporkan Laporan Kinerja (LAKIN) yang dibuat setiap tahunnya.

Pada laporan keuangan Balithi dapat dilihat LAKIN pada TA 2017-2018 sebagai berikut:

Tabel 1 Pagu dan Realisasi Belanja TA 2017-2018 (Dalam Rupiah)

\begin{tabular}{ccccc}
\hline Tahun & Uraian & $\begin{array}{c}\text { Anggaran } \\
\text { Pengeluaran } \\
(\text { Rp) }\end{array}$ & $\begin{array}{c}\text { Realisasi } \\
\text { Anggaran (Rp) }\end{array}$ & $\begin{array}{c}\text { Sisa } \\
(\text { Rp) }\end{array}$ \\
\hline $\mathbf{2 0 1 7}$ & $\begin{array}{c}\text { Anggaran } \\
\text { Belanja }\end{array}$ & 19.492 .978 .000 & 18.272 .378 .655 & 1.220 .599 .345 \\
\hline $\mathbf{2 0 1 8}$ & $\begin{array}{c}\text { Anggaran } \\
\text { Belanja }\end{array}$ & 19.586 .857 .000 & 19.042 .277 .991 & 544.579 .009 \\
\hline
\end{tabular}

Sumber : Balai Penelitian Tanaman Hias Kab.Cianjur, 2020

Tabel 2 Pagu dan Realisasi Pendapatan TA 2017-2018 (Dalam Rupiah)

\begin{tabular}{cccc}
\hline Tahun & $\begin{array}{c}\text { Anggaran } \\
\text { Pendapatan (Rp) }\end{array}$ & $\begin{array}{c}\text { Realisasi } \\
\text { Pendapatan (Rp) }\end{array}$ & $\begin{array}{c}\text { Rasio } \\
\text { Efektifitas (\%) }\end{array}$ \\
\hline $\mathbf{2 0 1 7}$ & 113.965 .000 & 283.533 .299 & $248,79 \%$ \\
\hline $\mathbf{2 0 1 8}$ & 118.965 .000 & 115.812 .754 & $97,35 \%$ \\
\hline
\end{tabular}

Sumber : Balai Penelitian Tanaman Hias Kab.Cianjur, 2020

Tabel 3 Persentase kinerja Balithi Kab. Cianjur Menggunakan Metode VFM Periode tahun 2017 sampai 2018

\begin{tabular}{cccc}
\hline \multirow{2}{*}{ Tahun } & \multicolumn{3}{c}{ Rasio } \\
\cline { 2 - 4 } & $\begin{array}{c}\text { Ekonomi } \\
(\%)\end{array}$ & $\begin{array}{c}\text { Efisiensi } \\
(\%)\end{array}$ & $\begin{array}{c}\text { Efektifitas } \\
(\%)\end{array}$ \\
\hline 2017 & 93,74 & 64,44 & $\mathbf{2 4 8 , 7 9}$ \\
\hline 2018 & 97,22 & $\mathbf{1 6 4 , 4 2}$ & $\mathbf{9 7 , 3 5}$ \\
\hline
\end{tabular}

Sumber : Balai Penelitian Tanaman Hias Kab.Cianjur, 2020

Pada tabel 1 dan tabel 2 dilihat berdasarkan anggaran belanja yang pada tahun 2017 dan 2018 dilihat secara total keseluruhan mengalami kenaikan. Akan tetapi di lihat berdasarkan anggaran pendapatan mengalami penurunan dari tahun 2017-2018. Sementara itu pada tabel 3 Dapat dilihat pada tabel diatas persentase kinerja Balithi Cianjur dengan menggunakan konsep VFM yang di peroleh dari Laporan Kinerja (LAKIN) terdapat anggaran pendapatan dan belanja, dimana rasio ekonomi diperoleh dari perbandingan anggaran pengeluaran (belanja) dengan realisasi pengeluaran. Secara keseluruhan dapat dilihat bahwa rasio ekonomis selama 2 tahun berturut- turut diatas $90 \%$ hal ini menunjukan bahwa Balithi mampu menghemat anggaran untuk memenuhi seluruh program kerja setiap tahunnya dan telah berhasil mengelola penggunaan anggaran belanja dengan baik.

Apabila dilihat dari segi efisiensi, dimana rasio efisiensi pada tahun 2017 menunjukan angka sebesar $64,44 \%$ dikategorikan efisien karena rasio kurang dari $75 \%$ dan mengalami kenaikan tahun 2018 menjadi $164,42 \%$ hal ini dikategorikan sangat efisien, hai ini menunjukan bahwa kinerja Balithi telah berhasil dalam pengelolaan anggaran yang dialokasikan. 
Dan dilihat dari segi efektifitas, Menunjukkan perbandingan antara pendapatan realisasi dan pendapatan yang dianggarkan, yang berarti 2 tahun tersebut kinerja Balithi karena realisasi anggaran pendapatan lebih kecil dengan anggaran pendapatan. Rasio efektivitas pada tahun 2017 menunjukan angka sebesar 248,79\% hal ini termasuk kategori yang sangat efektif karena nilai rasio lebih dari $75 \%$ tahun 2017 dan tahun 2018 menjadi $97,35 \%$ hal ini di kategorikan sangat efektif sesuai dengan penilaian persentase yang diperoleh.

Bastian (2006) Kinerja merupakan gambaran pencapaian pelaksanaan kegiatan/program/kebijaksanaan Untuk mencapai tujuan, sasaran, visi dan misi perusahaan/intansi. Kinerja merupakan kondisi yang harus dipahami dan dikonfirmasi oleh pihak tertentu. Menentukan tingkat pencapaian hasil organisasi terkait dengan visi organisasi / organisasi, dan memahami dampak positif dan negatif dari kebijakan operasi.

Mahsun (2013), kinerja (performance) ialah pembahasan mengenai level implementasi program/kebijakan dalam mewujudkan tujuan, sasaran, misi dan visi organisasi yang tertuang dalam perencancanaan strategis organisasi. Istilah kinerja lumrah digunakan untuk menyebut prestasi atau tingkat keberhasilan individu maupun kelompok individu.

Mardiasmo (2009), Indikator VFM dibagi menjadi dua bagian yaitu.

1) Indikator alokasi biaya (ekonomi dan efisiensi)

Ekonomi merupakan pembelian barang dan jasa dengan tingkat kualitas dan kualitas tertentu pada harga terendah. Tujuan ekonomi adalah menjadi ekonomis dan berhati-hati dalam menyediakan prosedur dan mengalokasikan sumber daya di IRCRI. Efisiensi berarti bahwa keluaran tertentu dapat direalisasikan dengan sumber daya sesedikit mungkin (pengeluaran yang wajar).

2) kualitas pelayanan (efektivitas)
Efektivitas mengacu pada kontribusi output terhadap realisasi tujuan dan sasaran yang ditetapkan.

Indikator kinerja sering diartikan dengan ukuran kinerja. Keduanya merupakan kriteria pengukuran kinerja dan terdapat perbedaan makna.

Indikator kinerja biasanya setara dengan indikator kinerja. Secara garis besar, keduanya merupakan standar pengukuran Performanya berbeda. Indikator kinerja secara tidak langsung mengacu pada evaluasi kinerja, yaitu hal-hal hanya mewakili kinerja, sehingga bentuknya biasanya kualitatif. Adapun ukurannya. Kinerja mengacu pada standar kinerja yang secara langsung mengevaluasi kinerja, sehingga bentuknya lebih bersifat kuantitatif. Indikator kinerja dan ukuran kinerja diperlukan untuk mengevaluasi tingkat pencapaian tujuan dan strategi.

\section{METODE PENELITIAN}

Objek dalam penelitian ini adalah LAKIN yang terdapat pada Satuan Kerja Balithiyang terletak di Jl. Raya Ciherang Pacet Kab. Cianjur. Desain penelitian adalah metode deskriptif. Tujuan dari desain ini hanya mengumpulkan fakta dan menguraikan secara menyeluruh dan teliti sesuai dengan persoalan yang akan di pecahkan, (Umar,1997) Penelitian deskriptif ini untuk menjawab pertanyaan berhubungan dengan keadaan tertentu dari subjek yang diteliti dan mendapatkan informasi mengenai LAKIN dengan menggunakan analisis VFM.

\section{Data dan Jenis Data}

Data yang digunakan dalam penelitian ini berupa kualitatif. Sugiono (2013) metode agar mendapatkan data yang objektif, data mengandung makna mendalam. Data primer diperoleh melalui wawancara langsung dengan pihak instansi pemerintah Balithi. Sedangkan data sekunder yang digunakan yaitu berupa dokumen perusahaan seperti data anggaran perusahaan berupa LAKIN tahun anggaran 2017-2018. 


\section{Metode Analisis Data}

Mahsun (2006) adapun teknik yang digunakan pada pengukuran kinerja salah satunya dengan menggunakan 3E yaitu ekonomis, efisien, dan efektifitas. Analisis VFM pada LAKIN berdasarkan tiga elemen ekonomi, efisien dan efektif tersebut menggunakan data anggaran berupa LAKIN tahun 2017-2018 bertujuan melihat pencapaian kinerja instansi pemerintah Balithi Kab. Cianjur.

\section{Ekonomi}

Bastian (2006), ekonomis (hemat) berhemat mencakup juga pengelolaan secara berhati-hati atau cermat dan tidak ada pemborosan/ tidak produktif. Jika biaya dapat dihilangkan atau dikurangi, aktivitas operasi dianggap ekonomis.

Kriteria ekonomi menurut Mahsun (2006) ialah:

Tingkat Ekonomis $=\frac{\text { Realisasi anggaran }}{\text { Anggaran Pengeluaran }} \times 100 \%$

Tabel 4 Kriteria Ekonomi Kinerja Keuangan

\begin{tabular}{|c|c|}
\hline $\begin{array}{l}\text { Presentase Kinerja } \\
\text { Keuangan }(\%)\end{array}$ & Kriteria \\
\hline $75 \%$ - keatas & Sangat ekonomi \\
\hline $60 \%-75 \%$ & Ekonomi \\
\hline $45 \%-60 \%$ & Cukup ekonomi \\
\hline $30 \%-45 \%$ & Kurang ekonomi \\
\hline Kurang dari $30 \%$ & Tidak ekonomi \\
\hline \multicolumn{2}{|c|}{ Sumber: Depdagri, Kepmendagri No 47, (1999) } \\
\hline $\begin{array}{l}\text { 2. Efisiensi } \\
\text { Pengukuran efisie }\end{array}$ & (berdaya guna) \\
\hline $\begin{array}{l}\text { dilakukan dengan } \\
\text { output yang dihasilk }\end{array}$ & $\begin{array}{l}\text { bandingan antara } \\
\text { dengan input yang }\end{array}$ \\
\hline $\begin{array}{l}\text { digunakan. Proses k } \\
\text { dapat dikatakan efi } \\
\text { yang dihasilkan. B } \\
\text { mengukur tingkat ef }\end{array}$ & $\begin{array}{l}\text { tan operasional ini } \\
\text { si apabila produk } \\
\text { ut formula untuk } \\
\text { nsi. }\end{array}$ \\
\hline $\begin{array}{l}\text { Tabel } 3.2 \text { Kriteria Efi } \\
\text { Sumber: Depdagri, K }\end{array}$ & $\begin{array}{l}\text { si Kinerja Keuangan } \\
\text { endagri No 47, (1999) }\end{array}$ \\
\hline 3. Efektivitas & \\
\hline $\begin{array}{l}\text { Efektivitas adalah } \\
\text { berhasil atau tidak } \\
\text { mencapai tujuan. } \mathrm{J} \\
\text { mencapai tujuan se } \\
\text { maka organisasi te } \\
\text { efektif. }\end{array}$ & $\begin{array}{l}\text { kuran pencapaian } \\
\text { organisasi dalam } \\
\text { organisasi berhasil } \\
\text { dengan tujuannya, } \\
\text { beroperasi secara }\end{array}$ \\
\hline
\end{tabular}

Tingkat Efektivitas $=\frac{\text { Realisasi Pendapatan }}{\text { Anggaran Pendapatan }} \times 100 \%$

Tabel 5 Kriteria Efektif Kinerja Keuangan

\begin{tabular}{cc}
\hline $\begin{array}{c}\text { Presentase Kinerja } \\
\text { Keuangan }(\%)\end{array}$ & Kriteria \\
\hline $75 \%-$ keatas & Sangat efektif \\
\hline $60 \%-75 \%$ & Efektif \\
\hline $45 \%-60 \%$ & Cukup efektif \\
\hline $30 \%-45 \%$ & Kurang Efektif \\
\hline Kurang dari $30 \%$ & Tidak efektif \\
\hline
\end{tabular}

Sumber: Depdagri, Kepmendagri No 47, (1999)

\section{HASIL DAN PEMBAHASAN}

1. Kondisi Kinerja yang dicapai oleh Balithi Kab. Cianjur pada periode tahun 2017-2018

Balai Penelitian Tanaman Hias (Balithi) didirikan berdasarkan Surat Keputusan Menteri Pertanian Nomor 796 / Kpts / OT / 210/12/1994 tanggal 13 Desember 1994. Balai Penelitian Tanaman Hias merupakan unit pelaksana teknis penelitian tanaman hias di bawah koordinasi Pusat Penelitian dan Pengembangan. Hortikultura. Badan Penelitian dan Pengembangan Pertanian. Dan struktur organisasi. Saya eselon III. Eselon IV dan eselon V enam serta jabatan fungsional lainnya.

Dalam rangka melaksanakan tugas pokok dan fungsinya Institut Tanaman Hias berkedudukan di Pasaminggu Jakarta. Bertanggung jawab atas 2 (dua) instalasi yaitu Instalasi Tanaman Hias Cipanas dan Instalasi Tanaman Hias Segunung. Dalam kurun waktu tujuh (tujuh) tahun (19952001), Balai Tanaman Hias menghasilkan berbagai teknologi tanaman hias unggulan. Termasuk bunga krisan. Mawar dan gladiol. Kegiatan Balai Tanaman Hias terus berkembang. Hasilnya adalah komersialisasi hasil penelitian melalui kerjasama antar Dinas, Intansi pemerintah, Universitas dan perusahaan swasta lainnya.

Balithi dalam tercapainya tujuan dan sasaran yang telah ditetapkan. Telah melaksanakan sub kegiatan penelitian dan 
pengembangan di bawah kegiatan dilingkup Puslitbang Hortikultura sebagai berikut :

1. Pengelolaan sumber daya genetik tanaman hias sebagai bahan perakitan VUB.

2. Perakitan VUB berdaya saing tahan terhadap cekaman lingkungan dan disukai konsumen.

3. Penyediaan teknologi produksi benih dan benih sumber bermutu tinggivarietas unggul tanaman hias.

4. Penyediaan teknologi produksi tanaman hias yang efisien dan antisipatif pada perubahan iklim.

5. Pengelolaan Organisme Pengganggu Tumbuhan(OPT) utama tanaman hias yang ramah lingkungan berbasis sumberdaya lokal.

6. Menganalisis kelayakan teknologi tanaman hias dan preferensi konsumen, menyebarluaskan dan menyarankan perkembangan inovasi tanaman hias.

7. Diseminasi dan rekomendasi pengembangan inovasi tanaman hias.

8. Kerjasama kemitraan pengembangan inovasi tanaman hias.

9. Peningkatan kapasitas dan Dan pengembangan kapasitas penelitian tanaman hias.

10. Meningkatkan kualitas kinerja unit pelayanan tanaman hias.

11. Pengembangan kapasitas teknologi informasi.

12. Kemitraan jejaring ilmu pengetahuan dan teknologi tanaman hias nasional dan internasional.

Balithi pada Tahun 2017-2018 telah menunjukkan kinerja yang sangat memuaskan. Tahun 2017 hasil pengukuran terhadap 3 sasaran kegiatan dengan 3 indikator kinerja terlihat bahwa capaian kinerjanya termasuk kategori keberhasilan di atas atau sama dengan $100 \%$ (sangat berhasil).

Capaian kinerja kegiatan litbang tanaman hias pada sasaran pertama dalam PK Balithi tahun 2018, yaitu
Dimanfaatkannya inovasi teknologi hortikultura realisasi 3 indikator dan Indeks Kepuasan Masyarakat (IKM) atas layanan publik Balithimenunjukan kinerja di atas atau sama dengan $100 \%$ (sangat berhasil).

Capaian Kinerja merupakan keberhasilan kegiatan litbang tanaman hias sesuai target sebelumnya dalam PK Balithi tahun 2017-2018. Dengan demikian, output tersebut diharapkan dapat dimanfaatkan oleh pengguna terutama petani dan swasta secara optimal. Balithi melakukan pemantauan terhadap kegiatan litbang tanaman hias secara berkala, yaitu setiap bulan (Laporan fisik bulanan), triwulan (Laporan Renaksi), dan tengah tahun (Laporan tengah tahun). Hal ini dilakukan untuk mengetahui, mengawal, dan memberikan rekomendasi perbaikan apabila terindikasi penyimpangan dari target output yang telah ditetapkan. Pengukuran capaian kinerja berdasarkan Indikator Keberhasilan Kinerja (IKK) terhadap Perjanjian Kinerja yang telah ditetapkan. Indikator keberhasilan kinerja ditetapkan berdasarkan kategori sebagai berikut: keberhasilan $\geq 100 \%$ (sangat berhasil), $80-<100 \%$ (berhasil), 60 $<80 \%$ (cukup berhasil), dan $<60 \%$ (kurang berhasil).

\section{Hasil Pengukuran Kinerja Metode VFM}

\section{a. Hasil Perhitungan Rasio} Ekonomi

Rasio ekonomi mengacu pada rasio ekonomi ketika kualitas dan kuantitas sumber daya (input) tertentu diperoleh dengan harga terendah atau pada harga yang mendekati harga pasar, atau perbandingan antara input yang dinyatakan dalam satuan dan nilai input mata uang. Pada pengukuran ekonomi dapat dilhat dari nilai anggaran belanja dan nilai realisasi belanja, adapun kegiatan penelitian di Balithi adalah: 
Tabel 6 Rasio Ekonomi Balithi Tahun 2017 sampai 2018

\begin{tabular}{|c|c|c|c|c|c|}
\hline No. & Uraian & $\begin{array}{l}\text { Anggaran } \\
\text { Pengeluaran } \\
\text { (Rp) }\end{array}$ & $\begin{array}{c}\text { Realisasi } \\
\text { Anggaran (Rp) }\end{array}$ & $\begin{array}{l}\text { Sisa } \\
\text { (Rp) }\end{array}$ & $\begin{array}{c}\text { Rasio } \\
\text { Ekonomi } \\
(\%)\end{array}$ \\
\hline \multicolumn{6}{|c|}{2017} \\
\hline 1 & Belanja Pegawai & 9.672 .978 .000 & 8.979 .630 .363 & 693.347 .637 & 92,83 \\
\hline 2 & $\begin{array}{l}\text { Belanja Barang } \\
\text { Operasinal }\end{array}$ & 3.324 .000 .000 & 3.124 .611 .843 & 199.388.157 & 94,00 \\
\hline 3 & $\begin{array}{l}\text { Belanja Barang } \\
\text { Non Operasional }\end{array}$ & 2.201 .000 .000 & 2.167.414.749 & 33.585 .251 & 98,47 \\
\hline 4 & Belanja Modal & 4.295 .000 .000 & 4.000 .721 .700 & 294.278 .300 & 93,15 \\
\hline & Total & 19.492 .978 .000 & 18.272 .378 .655 & 1.220 .599 .345 & 93,74 \\
\hline \multicolumn{6}{|c|}{2018} \\
\hline 1 & Belanja Pegawai & 8.812 .978 .000 & 8.587 .635 .552 & 225.342 .448 & 97,44 \\
\hline 2 & $\begin{array}{l}\text { Belanja Barang } \\
\text { Operasinal }\end{array}$ & 3.055 .816 .000 & 3.016.649.507 & 39.166 .493 & 98,72 \\
\hline 3 & $\begin{array}{l}\text { Belanja Barang } \\
\text { Non } \\
\text { Operasional }\end{array}$ & 3.495 .143 .000 & 3.408 .416 .645 & 86.726 .355 & 97,52 \\
\hline 4 & Belanja Modal & 4.222 .920 .000 & 4.029 .576 .287 & 193.343 .713 & 95,42 \\
\hline & Total & 19.586 .857 .000 & 19.042.277.991 & 544.579 .009 & 97,22 \\
\hline
\end{tabular}

Sumber: LAKIN Balithi Kab. Cianjur, Diolah, 2020

b. Hasil Perhitungan Rasio Efisiensi

Adapun hasil pengukuran efisiensi tahun 2017-2018 di Balithi ialah:

Tabel 7 Rasio Efisiensi Balithi Tahun 2017 -2018

\begin{tabular}{cccc}
\hline Tahun & $\begin{array}{c}\text { Realisasi } \\
\text { Pengeluaran } \\
(\mathbf{R p})\end{array}$ & Realisasi & $\begin{array}{c}\text { Rasio } \\
\text { Efisiensi } \\
(\boldsymbol{\%})\end{array}$ \\
\hline $\mathbf{2 0 1 7}$ & 18.272 .378 .655 & 283.533 .299 & 64,44 \\
\hline $\mathbf{2 0 1 8}$ & 19.042 .277 .991 & 115.812 .754 & 164,42 \\
\hline
\end{tabular}

Sumber: LAKIN Balithi Kab. Cianjur, Diolah, 2020

\section{c. Hasil Perhitungan Rasio Efektivitas}

Dengan membandingkan realisasi pendapatan dengan anggaran pendapatan yang ditetapkan oleh Balithi untuk tahun anggaran 2017-2018 diperoleh hasil perhitungan evaluasi kinerja, hasil pengukuran tersebut, ialah sebagai berikut:

Tabel 8 Rasio Efektifitas Balithi Tahun 2017 -2018

\begin{tabular}{cccc}
\hline Tahun & $\begin{array}{c}\text { Anggaran } \\
\text { Pendapatan }(\mathbf{R p})\end{array}$ & $\begin{array}{c}\text { Realisasi } \\
\text { Pendapatan (Rp) }\end{array}$ & $\begin{array}{c}\text { Rasio } \\
\text { Efektifitas (\%) }\end{array}$ \\
\hline $\mathbf{2 0 1 7}$ & 113.965 .000 & 283.533 .299 & $248,79 \%$ \\
\hline $\mathbf{2 0 1 8}$ & 118.965 .000 & 115.812 .754 & $97,35 \%$ \\
\hline
\end{tabular}

Sumber: LAKIN Balithi Kab. Cianjur, Diolah, 2020 


\section{HASIL PENELITIAN DAN PEMBAHASAN}

\section{Pembahasan kondisi Kinerja yang dicapai oleh Balithi Kab. Cianjur pada periode tahun 2017-2018}

Hasil pengukuran kinerja Tahun 2018 berdasarkan PK tahun 2018. Pada semua indikator tersebut, dicapai realisasi sebesar $\geq 100 \%$ sehingga dapat dikatagorikan sangat berhasil. Pengukuran telah dilakukan terhadap 2 sasaran, yaitu 1) Dimanfaatkannya inovasi teknologi hortikultura (3 indikator) dan 2) Meningkatnya kualitas layanan publik Balithi Pertanian BioIndustri (1 indikator). Sedangkan pada sasaran point tiga, yaitu Terwujudnya akuntabilitas kinerja instansi pemerintah di lingkungan Balai Penelitian Tanaman Hias, dengan Jumlah temuan Itjen atas implementasi SAKIP belum dapat dilakukan karena belum ada penilaan oleh Itjen.

Persentase capaian kinerja jumlah VUB krisan dan anggrek Tahun 2017 dan 2018 masih tetap stabil di atas 100,00\%. Persentase capaian tersebut termasuk kategori keberhasilan sangat berhasil, Persentase capaian jumlah koleksi/ karakterisasi SDG tanaman hias Tahun 2018 stabil sebesar 100,00\%, Kinerja tahun 2018 masih konsisten dengan kinerja tahun sebelumnya., yaitu termasuk ke dalam kategori di atas atau sama dengan $100,00 \%$ (sangat berhasil).

Persentase capaian jumlah benih sumber krisan Tahun 2018 lebih rendah (101,84\%) daripada tahun 2017 $(100,00 \%)$. Target produksi krisan tahun 2017 (100,000 stek) mengalami penurunan dari tahun sebelumnya karena anggarannya sangat terbatas, anggaran yang ada hanya diprioritaskan untuk pemeliharaan, produksinya juga terbatas untuk mendukung kegiatan diseminasi inovasi tanaman hias, kerjasam penelitian dan melayani permintaan Direktirat Jenderal Hortikultura dalam jumlah terbatas. Namun demikian, capaian kinerja benih sumber krisan Tahun 2018 Sejalan dengan kinerja tahun sebelumnya, yaitu termasuk ke dalam kategori di atas atau sama dengan 100,00\% (sangat berhasil).

Capaian jumlah benih sumber anggrek dan tanaman hias lainnya tahun 2018 paling tinggi $(105,72)$ dari pada tahun 2017 (0,00\%), Persentase capaian benih sumber pada tahun 2017 sangat rendah $(0,00 \%)$ karena anggaran yang ada sangat terbatas dan hanya diprioritaskan pada kegiatan pemeliharaan seperti melakukan subkultur di laboratorium, serta tidak melakukan kegiatan produksi. Meskipun demikian, capaian kinerja benih sumber anggrek dan tanaman hias lainnya masih konsisten dengan capaian kinerja pada 3 tahun sebelumnya, yaitu termasuk ke dalam kategori di atas atau sama dengan 100,00\% (sangat berhasil).

Persentase capaian jumlah teknologi perbanyakan varietas unggul anggrek Tahun 2018 tetap stabil, yaitu sebesar $100,00 \%$ (sangat berhasil), meskipun target volume output pada tahun 2018 lebih rendah (2 teknologi), Hal ini dikarenakan pada tahun 2017, kegiatan tersebut mengalami penurunan anggaran yang cukup besar.

Balithi sejak tahun 2017 telah mengoptimalkan kinerjanya supaya dapat memenuhi standar tersebut, sehingga akhirnya pada bulan Desember 2017 ditetapkansebagai lembaga binaan PUI) Kemenristek Dikti. Balithi melalui Surat Keputusan Kemenristek Dikti ditetapkan menjadi salah satu lembaga litbang yang dibina menjadi PUI dari 30 kandidat yang dinyatakan lolos seleksi dengan peraihan poin diatas 700 , yaitu 825 . Balithi pada tahun 2018 telah lulus melewati masa pembinaan 1 tahun, selanjutnya dikukuhkan menjadi Pusat Unggulan Iptek (PUI) oleh Kemenristek Dikti dalam acara bertajuk "Apresiasi Lembaga Penelitian dan Pengembangan Tahun 2018" di Auditorium Kemenristekdikti Jakarta bersama sejumlah lembaga PUI lainnya pada tanggal 13 Desember 2018. Balithi melalui Surat Keputusan Kemenristek Dikti ditetapkan menjadi salah satu lembaga litbang menjadi PUI dengan nilai 
sebesar 941,83/1.000. Balithi berkomitmen menjalankan PUI Pemuliaan Tanaman Hias pada tahun 2019 dan mempertahankannya untuk periode selanjutnya (marsudi et al,2019).

Capaian kinerja terhadap sasaran kegiatan Balithi Tahun 2017-2018 dipengaruhi oleh beberapa faktor internal dan eksternal. Faktor internal antara lain: (1) adanya monitoring dan evaluasi kegiatan penelitian dan diseminasi sejak tahap perencanaan, pelaksanaan hingga tahap akhir, sehingga fungsi pengawasan terhadap setiap tahapan kegiatan dapat berjalan dengan baik; dan (2) sarana dan prasarana penelitian cukup memadai untuk mendukung kegiatan penelitian, seperti laboratorium, fasilitas komputer, jaringan internet, perpustakaan, sarana kendaraan, dan lain-lain. Selain itu, faktor-faktor eksternal juga mempengaruhi keberhasilan kegiatan penelitian dan diseminasi ialah terjalinnya komunikasi dan koordinasi dengan instansi terkait di lingkup Kementerian Pertanian seperti Direktorat Perbenihan dan Sarana Prasarana Hortikultura, Direktorat Buah dan Florikultura, serta BPTP maupun instansi di luar Kementerian Pertanian seperti Pemerintah Provinsi/Daerah, Perguruan Tinggi, pihak swasta maupun asosiasi tanaman hias dan floris.

Capaian kinerja lainnya di samping yang telah ditargetkan di dalam Perjanjian Kinerja tahun 2018 dan IKU tahun 2018, yaitu Balithi mendapat TREASURY AWARD untuk penghargaan sebagai Peringkat IV dalam Kinerja Pelaksanaan Anggaran Terbaik pada kategori satker pagu besar lingkup Kanwil Ditjen Perbendaharaan Prov. Jabar Tahun 2017.

\section{Pembahasan Hasil Perhitungan Ekonomi}

\section{a. Pembahasan Hasil Perhitungan Ekonomi TA 2017-2018}

Hasil perhitungan LAKIN

Menggunakan rasio ekonomi 2017-2018 dengan menggunakan metode VFM dilaksanakan oleh Balithi dengan ekonomis. Dari tabel di atas, perkembangan rasio ekonomis Balithi sangat konsisten berada pada katagori ekonomis, hal ini dapat dilihat dari total anggaran yang di sediakan setiap tahunnya, tidak habis terpakai dalam memenuhi seluruh program kerja setiap tahunnya dengan nilai rata-rata output yang dihasilkan hampir mencapai maksimal yaitu sebesar $93,74 \%$ pada tahun 2017 dan pada tahun 2018 sebesar 97,22\%, Tahun 2017 merupakan tahun di mana terjadi penghematan anggaran terbesar dari total anggaran Rp. 19.492.978.978,- dan pada pelaksanaan kegiatan anggaran yang dipakai hanya sebesar Rp. 18.272.378.655,-dengan berarti telah terjadi nya penghematan anggaran sebesar Rp. 1.220.599.345,-, Pada tahun 2018 total anggaran yang disediakan yaitu sebesar Rp. 19.586.857.000,- dan pada proses pelaksanaan program kerjanya hanya sebesar Rp. 19.402.272.991,-, dengan penghematan anggaran sebesar Rp. 544.579.009,- meski penghematan anggaran tahun ini lebih kecil dibandingkan tahun sebelumnya akan tetapi nilai rata-rata output seluruh program kerjanya hampir mencapai maksimal, yaitu di atas $90 \%$ dikategorikan sangat ekonomis.

\section{b. Pembahasan Hasil Perhitungan Efisiensi TA 2017-2018}

Pengukuran Rasio Efisiensi bertujuan untuk mengetahui Kinerja Balithi dalam menggunakan sumber daya input yang tersedia untuk menghasilkan keluaran/ output.

Kinerja Balithi pada tahun 2017 dari segi efisiensi menunjukkan kinerja yang efisien. Hal ini dapat dilihat dari rasio efisiensi pada tahun 2017 adalah 64,44\% termasuk kedalam kategori efisien, ini menunjukkan tingkat efisiensi baik karena persentase kurang dari $100 \%$, dengan kata lain Balithi berhasil meningkatkan pendapatan melebihi realisasi belanjanya, sedangkan pada tahun 2018 besarnya tingkat efisiensi Balithipada tahun 2018 adalah $164,42 \%$ masuk ke dalam kategori sangat efisien, ini menunjukkan tingkat 
efisiensi sangat baik karena persentase diatas $75 \%$, dengan kata lain Balithi mampu meningkatkan pendapatan untuk mengimbangi realisasi belanjanya.

\section{c. Pembahasan Hasil Perhitungan Efisiensi TA 2017-2018}

Kineja Balithi pada tahun 2017 sampai tahun 2018 dari segi efektifitas, hasil penelitian efektivitas dikatakan sangat efektif apabila perhitungannya lebih dari 75\% Untuk mencapai maksud dan tujuan dari masing-masing kegiatan dapat diketahui bahwa efisiensi rata-rata telah mencapai $90 \%$, sedangkan tujuan

Tabel 9 Rasio Ekonomi, Efisiensi dan Efektifitas Balithi Kab, Cianjur Periode tahun 2017 sampai 2018

\begin{tabular}{cccc}
\hline & \multicolumn{3}{c}{ Rasio } \\
\cline { 2 - 4 } Tahun & Ekonomi $(\%)$ & $\begin{array}{c}\text { Efisiensi } \\
(\%)\end{array}$ & $\begin{array}{c}\text { Efektifitas } \\
(\%)\end{array}$ \\
\hline 2017 & 93,74 & 64,44 & 248,79 \\
\hline 2018 & 97,22 & 164,42 & 97,35 \\
\hline
\end{tabular}

Sumber: LAKIN Balithi Kab. Cianjur, 2020

Pada tabel 4.4 menunjukkan bahwa kinerja Balithitahun 2017 sampai dengan 2018 dapat dikatakan telah memenuhi syarat VFM itu ekonomi efisiensi dan efektivitas hal ini dapat ditunjukkan oleh nilai rata-rata, efisiensi dan efektivitas yang diperoleh yang mencapai angka 60 sampai lebih dari $100 \%$ berdasarkan presentasi uraian pada bab sebelumnya.

Rasio efisiensi menunjukan angka sebesar 64,44\% dikategorikan efisien pada tahun 2017 dan mengalami kenaikan menjadi $164,42 \%$ hal ini dikategorikan sangat efisien, hai ini menujukan bahwa kinerja Balithitahun 2017 mengalami peningkatan pada tahun 2018 dalam pengelolaan anggaran yang dialokasikan.

Rasio efektivitas tahun 2017 sebesar 248,79\% dan tahun 2018 sebesar $97,35 \%$ hal ini di kategorikan sangat efektif karena lebih dari $75 \%$.

Kegiatan operasial dengan program kerja yang dimiliki telah berjalan sesuai dengan target yang diharapkan dengan terjadinya penghematan anggaran di setiap tahunnya yaitu ekonomis. Penelitian ini sejalan dengan Ardila (2015) dalam hasil pencapaian tujuan tersebut setiap kegiatan ini terlihat bahwa rasio efektivitas rata-rata telah mencapai persentasi maksimal $100 \%$, tahun 2017 rasio efektivitas mencapai $248,79 \%$ termasuk ke dalam kategori sangat efektif karena persentasi lebih dari 75\%, dan pada tahun 2018 rasio efektivitas mencapai $97,35 \%$ termasuk ke dalam kategori sangat efektif, dengan demikian penulis menyimpulkan bahwa kinerja Balithi melalui analisis Kinerja VFM termasuk kategori sangat efektif karena lebih dari $75 \%$.

penelitian pada tempat yang berbeda tetapi sama-sama melakukan pengukuran kinerja dengan menggunakan analisis VFM . Hal serupa yang sama Andhi dkk (2013) melakukan Pengukuran Kinerja dengan Pendekatan VFMsebagai Perwujudan Good Governance pada Dinas Kesehatan Kota Madiun.

\section{KESIMPULAN}

Berdasarkan data kesimpulan yang ditarik dari hasil analisis data adalah:

1. Kinerja yang dicapai oleh Balithi Kab. Cianjur telah menunjukkan kinerja yang sangat memuaskan. Hasil evaluasi kinerja dari tahun 2017 hingga 2018 menunjukkan bahwa semua pencapaian kinerja termasuk sasaran kegiatan dan indikator kinerja termasuk dalam kategori sukses dan lebih tinggi dari atau sama dengan 100\% (sangat berhasil). sesuai kriteria perhitungan Balithi Kab. Cianjur yang terdapat dalam LAKIN.

2. Berdasarkan data yang diperoleh dengan menggunakan hasil analisis 
data metode VFM maka dapat ditarik kesimpulan sebagai berikut:

a. Ekonomi

Kineja Balithi Kab. Cianjur pada tahun 2017 sampai tahun 2018 dari segi ekonomi menunjukan kinerja yang sangat ekonomis. Dengan rasio sebesar $93,74 \%$ pada tahun 2017 dan tahun 2018 sebesar $97,22 \%$.

b. Efisiensi

Kineja Balithi Kab. Cianjur Pada tahun 2017 menunjukkan kinerja yang efisien dalam hal efisiensi. Hal ini terlihat dari kategori efisiensi pada tahun 2017 sebesar $64,44 \%$ sedangkan tingkat efisiensi Balithi tahun 2018 sebesar $164,42 \%$. masuk ke dalam kategori sangat efisien. Artinya Balithi mampu meningkatkan pendapatan untuk mengimbangi realisasi belanjanya.

c. Efektivitas

Kineja Balithi Kab. Cianjur pada tahun 2017 sampai tahun 2018 dari segi efektifitas, hasil penelitian efektivitas dikatakan sangat efektif karena rasionya lebih dari $70 \%$, tahun 2017 rasio efektivitas mencapai $248,79 \%$ dan pada tahun 2018 rasio efektivitas mencapai 97,3\% dengan demikian penulis menyimpulkan bahwa kinerja Balithi Kab. Cianjur melalui analisis Kinerja VFM termasuk kategori sangat efektif.

\section{SARAN}

1. Kinerja Balai Penelitian Tanaman Hias pada tahun 2017 sampai 2018 telah melaksanakan kegiatannya dengan ekonomis, efisien dan efektif, maka diharapkan untuk kedepannya mampu mempertahankan atau dapat ditingkatkan dari tahun ke tahun berikutnya. Balithi dapat menghasilkan output (Program kerja) yang lebih baik lagi dari pada sebelumnya.
2. Penggunaan anggaran yang tidak melebihi dari yang telah ditetapkan bukan merupakan satu-satunya patokan penilaian kinerja harus dibandingkan dengan output yang telah dihasilkan.

3. Untuk kedepannya semoga Balithi dapat meningkatkan pendapatan untuk mengimbangi realisasi belanjanya, agar lebih efisien.

4. Apabila peneliti lain tertarik untuk mengadakan penelitian yang hampir sama, sebaiknya agar mengambil sampel yang lebih luas lagi, agar generalisasi dapat dilakukan dengan baik jelaskan tiga elemen rasio (ekonomi, efisiensi, dan efektivitas) yang dijadikan patokan penilaian kinerja dalam penelitian ini. Peneliti menyarankan rasio yang lain sebagai pendukung kebijakan tersebut seperti rasio kemandirian dan rasio keadilan atau bias menggunakan pengukuran kinerja dengan metode yang lain.

\section{DAFTAR PUSTAKA}

Andhi Sulistyanto, Isharijadi dan Nuraina. 2013. Analisis Pengukuran Kinerja dengan Pendekatan VFM Sebagai Perwujudan Good Governance Pada Dinas Kesehatan Kota Madiun. ISSN: 2337-9723.

Angraini, Magfirah., Andi Mattulada Amir Dan Nina Yusnita. 2018. Pengelolaan Penerimaan Negara Bukan Pajak: Suatu Tinjauan Evaluatif (Studi Pada Satuan Kerja Kantor Pertanahan Kab. Parigi Moutong). 24 Katalogis, Volume 6 Nomor 5 hlm 23-34.

Ardila, I, dan Putri, A, A. 2015. Analisis

Kinerja Keuangan Dengan Pendekatan VFM Pada Pengadilan Negeri Tebing Tinggi. JRAB : Jurnal Riset Akuntansi dan Bisnis 15.(1). 
Arthasari. Yuli. 2011. Pengukuran Kinerja Pemerintah Daerah Kab. Magetan Dengan Menggunakan Metode VFM. Skripsi Ekonomi Akuntansi. Universitas Muhammadiyah Malang.

Barnett, C., et.al. 2010. Measuring the Impact and VFM of Governance \& Conflict Programmes. Final Report December.

Bastian. Indra. 2006. Akuntansi sektor publik: suatu pengantar. Jakarta: Salemba Empat.

Bastian. Indra. 2007. Sistem Akuntansi sektor publik: suatu pengantar. Jakarta: penerbit. Erlangga.

Departemen Dalam Negeri. Keputusan Menteri Dalam Negeri Nomor 47 Tahun 1999 tentang Pedoman Penilaian Kinerja.

Donaldson, Lex dan Davis, James, $\mathrm{H}$. 1991. Stewardsship Theory or Agency Theory: CEO Governance and Skateholder Returns. Australian Journal of Management.

Halim, A. 2007. Akuntansi Sektor Publik : Akutansi Keuangan Daerah. Edisi Ketiga. Jakarta : Salemba Empat.

Hongren dan Sundem. 2002. Introduction to Management Accounting, $12^{\text {th }}$ edition, New Jersey: Pentice-Hall International Inc.

Kaplan dan Norton, 2000. Balanced Scorecard: Menerjemahkan Srategi Menjadi Aksi. Jakarta: Erlangga.

Lasmana, A., \& Nofiyati, N. (2017). Analisis Kinerja Manajerial Berdasarkan Penerapan Akuntansi Pertanggungjawaban, Partisipasi Anggaran Dan Implementasi Strategi Pada Pdam Tirta Pakuan Kota Bogor. JURNAL AKUNIDA, 3(1), 40-54.

Mahmudi. 2010. Manajemen kinerja sektor publik. Edisi revisi. Yogyakarta: UPP STIM YKPN.
Mardiasmo. 2002. Akuntansi Sektor Publik. Yogyakarta: Andi Yogyakarta.

Mardiasmo. 2003. Perpajakan Edisi Revisi. Yogyakarta: Andi Offset.

Mardiasmo. 2004. Otonomi dan Manajemen Keuangan Daerah. Yogyakarta: Andi Yogyakarta.

Mardiasmo. 2005. Akuntansi Sektor Publik Edisi 2. Yogyakarta: Andi Yogyakarta.

Mardiasmo. 2009. Akuntansi Sektor Publik. Yogyakarta: Andi Yogyakarta.

Marsudi, J., Supradi, A., \& Susandra, F. (2019). Tingkat Kemandirian, Efisiensi, Efektivitas, Dan Pertumbuhan Pendapatan Asli Daerah: Kajian Pada Provinsi Jawa Barat. JURNAL AKUNIDA, 5(2), 32-46.

Setiawan, A. B., \& Tami, R. P. (2018).

Pengaruh Penerapan SAP Dan SPIP Terhadap Kualitas Laporan Keuangan Pemerintah Daerah Kota Bogor Dengan Kompetensi SDM Sebagai Variabel Moderating. JURNAL

AKUNIDA, 4(1), 76-89.

Setiawan, A.B, dan W. Gustina. 2016. Analisis VFM Pada Laporan Akuntabilitas Kinerja Instansi Pemerintah (LAKIP) Balai Penelitian Ternak Ciawi Bogor. JURNAL AKUNIDA ISSN 24423033 Volume 2 Nomor 2.

Sugiyono. 2013. Metode Penelitian Pendidikan Pendekatan Kualitatif dan Kuantitatif Dan $R \& D$. Bandung: ALFABETA.

Umar, Husein. 1997. Riset Akuntansi. PT. Gramedia Pustaka Utama. Jakarta.

Wiwik. 2013. Pengukuran kinerja sektor publik dengan analisis VFM (studi kasus pada pemerintah daerah Kab.Bojonegoro). Skripsi. Universitas Muhammadiyah Malang.

Yuandra, Angel. (2007). Pengukuran Kinerja Organisasi Sektor 
Publik Pendekatan Value For

Money (studi kasus pada

Pemerintahan Kota Blitar).
Skripsi tidak di terbitkan. Fakultas

Ekonomi UMM, Malang. 